\title{
Government spending cycles: Ideological or opportunistic?*
}

\author{
HENDRIK P. VAN DALEN \& OTTO H. SWANK \\ Research Center for Economic Policy (OCFEB), Erasmus University Rotterdam, P.O. Box \\ 1738, 3000 DR Rotterdam, The Netherlands, and Tinbergen Rotterdam-Amsterdam Center \\ for Economics (TRACE)
}

Accepted 24 January 1996

\begin{abstract}
This paper examines whether partisan and opportunistic motives affect government expenditure growth in the Netherlands. The time series analysis, covering the period 19531993, allows for different types of government spending. In general, spending is inspired by ideological and opportunistic motives: all government expenditure categories show an upward drift during election times and the 'partisan' motives behind government spending are clearly revealed: left-wing cabinets attach greater importance to social security and health care than right-wing cabinets and right-wing cabinets value expenditure on infrastructure and defense more than left-wing parties.
\end{abstract}

\section{Introduction}

Modern-day political economic theory is characterized by a plethora of models emphasizing at one time the benign government agent providing the median voter the public goods he demands, at another instant the opportunistic policy maker trying to fool the public during elections, or at still another point in time the ideological or 'partisan' policy maker who represents the interest of a certain group in society and who designs policies that are favourable to those groups.

The first wave of the political cycles literature originated with a precursory article by Kalecki (1943). The literature developed rapidly some thirty years later by the introduction of Nordhaus's (1975) Political Business Cycle (PBC) model and Hibbs's (1977) partisan model. In the PBC model, political cycles stem from the policy makers' incentives to create booms in election years in order to increase their chances of reelection. In the partisan model, different political parties have different preferences over economic goals, so that the alternation of parties in office leads to political cycles. In Frey and Schneider (1978a, 1978b) the PBC model and the partisan model are reconciled. In their model, the party in office implements partisan policies when reelection is

* Constructive comments by Frans van Winden, Wilko Letterie, Peter Cornelisse, Arie Ros, André de Moor, Harry ter Rele and an anonymous referee are gratefully acknowledged. 
safe, but generates an electoral cycle when the prospects for reelection are poor.

The second wave of studies on political cycles was a reaction to the "rational expectations' critique, most fervently expressed by Lucas (1976). The assumption underlying earlier studies that economic agents in general and voters in particular can be systematically fooled was relaxed. Alesina (1987) was one of the first to develop a rational expectations version of the partisan model. The predictions of his model deviate from those of the Hibbs model in that cycles in real variables only occur in the first part of each administration's term. Persson and Tabellini (1990) show that even when voters are rational and forward-looking, political business cycles may exist if voters have incomplete information about the competency of the government.

Most of the empirical research on political cycles is based on highly aggregated, macroeconomic variables, such as national output growth, unemployment, inflation or money aggregates. The evidence of the Nordhous model is mixed. For the United States, Haynes and Stone (1989) report evidence of PBCs in output growth, the unemployment rate and inflation, but McCallum (1978) and more recently Alesina and Roubini (1992) find weak or no evidence. Alesina, Cohen, and Roubini (1992) examine evidence of the PBC model for eighteen OECD countries. Only for Germany and New Zealand monetary policy is found to be consistent with the PBC model. As to fiscal policies the evidence of the PBC model is somewhat stronger. Alesina (1988) and Tufte (1978) find that in the United States transfer payments tend to be increased during election years and Alesina, Cohen, and Roubini (1992) report (irregular) PBCs in budget deficits using panel data for eighteen countries. The evidence of the (rational) partisan model is relatively strong, at least for the United States (see Alesina, 1988).

As mentioned earlier, evidence is mainly presented in terms of macroeconomic variables. Few authors have tried to detect political cycles in government expenditures on specific types of public goods and quasi-public goods. We regard this as a lacuna in the literature because recent theoretical studies on political cycles focus on how elections may affect government spending. Rogoff and Sibert (1988) and Rogoff (1990) present a model in which office seeking policy makers may increase government spending on highly visible projects in election years to signal their competency to incompletely informed voters. Tabellini and Alesina (1990) have shown in a different set-up why government deficits arise, a phenomenon that is explained by the conflict between parties on the composition of the government expenditures and the inability of current voters to bind the choices of future voters. Moreover, several countries participate in a fixed exchange rate regime or have delegated monetary policy to an independent central bank. In those countries monetary 
instruments cannot be employed for achieving electoral or partisan goals so that the policy makers have to rely on the mix of fiscal instruments.

In this paper we take the logical step suggested by the recent theories on political cycles and examine whether various categories of government spending exhibit political cycles. To test for political effects on various categories of public spending, we need a structural model of government spending. We rely on the public goods model first used by Borcherding and Deacon (1972). In this model the amount of public goods provided by the government depends on income, relative prices, and population size.

We apply the analysis to the Netherlands. We find the case of the Netherlands interesting for a number of reasons. First, the Netherlands has almost always participated in a fixed exchange rate regime. Against this background it is hardly surprising that Dutch monetary instruments are never found to exhibit clear political cycles. Examining the discretionary power of cabinets with respect to the composition and level of public spending therefore seems like a sensible research strategy. Furthermore to test the implications of the Rogoff model and to examine the empirical relevance of the Tabellini-Alesina model one needs to examine government behaviour on a relatively low level of aggregation. In order to explore this possibility we examine data published by the Central Planning Bureau on various categories of public expenditures for the Netherlands, including expenditures on defense, infrastructure, public administration, health care, education and social security transfers. The second reason is that in the post-war period the Netherlands has only known coalition governments. It is often claimed that in such a political setting political cycles are less likely to occur than under conditions of a two-party system (Alesina and Rosenthal, 1995). Third, there exists relatively little research on political cycles in government expenditures for the Netherlands. An exception is Renaud and Van Winden (1987) who have tested the Frey and Schneider model for the Netherlands. Using aggregate data on government expenditures, they found no clear evidence for political cycles.

This paper is organized as follows. The next section presents a general outline of the theoretical models of government spending that will be tested in this paper. Section 3 briefly discusses the data and in Section 4 we report the empirical results. Section 5 concludes the paper.

\section{The public goods model}

The central theme of this paper revolves around the question whether government spending is motivated by ideological or opportunistic motives. Some recent studies emphasize the influence of elections on political decisions. Two strands in this literature can be distinguished. The first deviates from the 
public goods model in that voters are imperfectly informed about the policy maker's competence, i.e., the policy maker's ability to provide public goods efficiently (Rogoff, 1990). Naturally, voters prefer a competent policy maker to an incompetent policy maker. This induces a competent policy maker to signal his competence by providing more public goods than socially desired. This type of models predicts that near elections public output is on average relatively high. The second strand in this literature focuses on partisan cycles in policies. The main assumption is that each political party caters to the desires of its core constituencies. As a consequence, a change in the political colour of the cabinet may lead to changes in the size or composition of public spending (see Renaud and Van Winden, 1987).

It would, however, be rather bold to state that government spending is solely determined by the ideological motives of the members of a cabinet. The opinion of the (median) voter also matters. The interplay between the median voter and the incumbent government in questions of government spending has been used extensively in the economic approach to the size of the government. The 'public goods' model is based on conventional price theoretic principles, emphasizing individual preferences for public goods and the costs of the provision of those goods (Borcherding and Deacon, 1972; Bergstrom and Goodman, 1973). As to the supply side of public activities, it is assumed that politicians seek office. Under conventional assumptions about voters' preferences, the level of public activities chosen by the elected policy maker coincides with the median voter's demand for public activities. This approach leads to the prediction that the size of the government varies with the median voter's income, the price of public goods relative to the price of private goods and the population size (or density). Several authors have tried to assess the income and price elasticity for public activities (see, for a survey, Borcherding, 1985). Most of them report an income elasticity smaller than 1 and a price elasticity greater than -1 , thereby rejecting a rigid interpretation of Wagner's law and providing support to Baumol's 'cost-disease' hypothesis, i.e., the hypothesis that the growth of government is caused by the relative increase in the price of public goods and services, which are assumed to be produced under technologically inferior conditions compared to the private sector.

The time-series analysis of this paper is based on the following equation, adopted from the public goods model:

$$
\mathrm{G}_{\mathrm{it}}=\mathrm{Z}_{\mathrm{it}}\left(\frac{\mathrm{Y}_{\mathrm{t}}}{\mathrm{N}_{\mathrm{t}}}\right)^{\alpha_{1}}\left(\frac{\mathrm{P}_{\mathrm{it}}}{\mathrm{P}_{\mathrm{Yt}}}\right)^{\alpha_{2}} \mathrm{~N}_{\mathrm{t}}^{\alpha_{3}}
$$

Where $G_{i t}$ is real government expenditures on good $i$ at time $t, Y_{t} / N_{t}$ is per capita income, $\mathrm{P}_{\mathrm{it}} / \mathrm{P}_{\mathrm{yt}}$ is the price of $\mathrm{G}_{\mathrm{it}}\left(\mathrm{P}_{\mathrm{it}}\right)$ relative to the price of private 
goods $\left(\mathrm{P}_{\mathrm{yt}}\right)$, and $\mathrm{N}_{\mathrm{t}}$ denotes the total population size. Finally, $\mathrm{Z}_{\mathrm{it}}$ represents all other factors that affect the demand for public goods. In principle, (1) is the basic equation used by authors following the traditional economic approach.

In Section 4 we examine the effects of elections and ideology on various categories of government spending in the Netherlands. We base the empirical analysis on (1). To test for electoral and ideological cycles $Z_{\text {it }}$ includes an electoral dummy variable and a variable measuring the ideological characteristics of the government. Furthermore, $Z_{i t}$ includes autoregressive terms, a constant, a trend variable and various measures of the composition of the Dutch population.

\section{Data}

To estimate equation (1) we need time series on public expenditures, income and population size. The figures on public expenditure are extracted from the Central Planning Bureau (CPB, 1994) and GDP and population figures are based on the National Accounts of the Central Bureau of Statistics (CBS). In the absence of data on the median income we will use per capita GDP as an approximation. For a detailed description of the data we refer to these publications. In the appendix to this paper we present the definitions of the data used. The political variables are constructed by employing data on elections and cabinet composition (Daalder and Schuyt, 1991). Some of the details of the data are given in the sections below.

\subsection{Government expenditures}

We consider the following number of expenditure categories: defense, infrastructure, public administration, health care, education, and social security benefits. Figures 1a through 1f show the time series properties for each category, where expenditures are expressed as a percentage of GDP at current prices.

The most striking feature of these pictures is that each and every category has a distinct different history, thereby bringing home the point that a disaggregate analysis of government expenditure is a potentially worthwhile exercise. Apart from the differences between the various ratios of expenditure categories there are some similarities. All expenditure ratios rose in the first two decades of the sample period, except for the expenditures on defense. At the end of the sample period all, save one, expenditure ratios declined. The reversals of the expenditure ratios began at different times. Expenditure on infrastructure started to decline at the end of the sixties, education expenditure in the mid-seventies and expenditure on public administration and transfer payments in the eighties. Only for the expenditure on health care we observe 
(a) DEFENSE

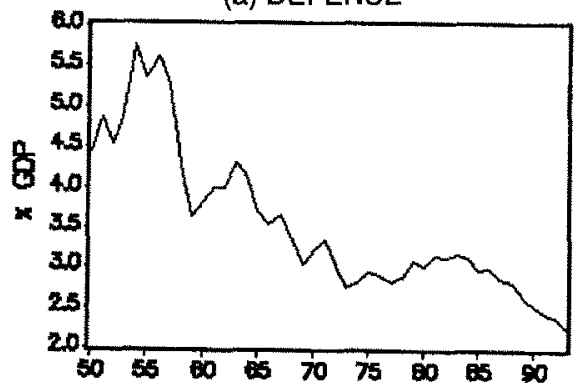

(c) PUBLIC ADMINISTRATION

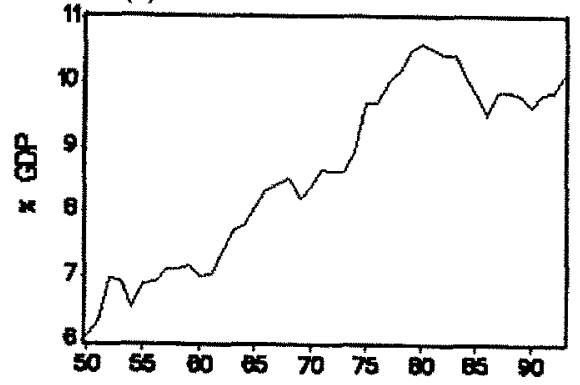

(e) INFRASTRUCTURE

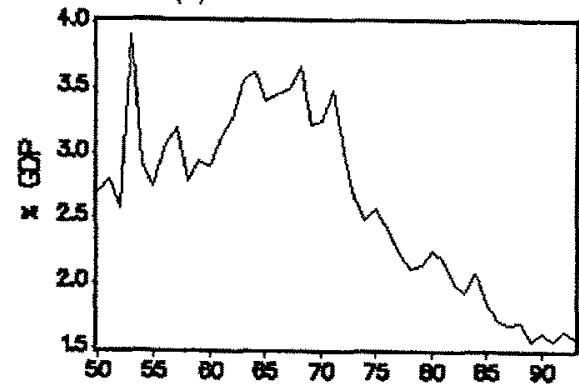

(b) EDUCATION

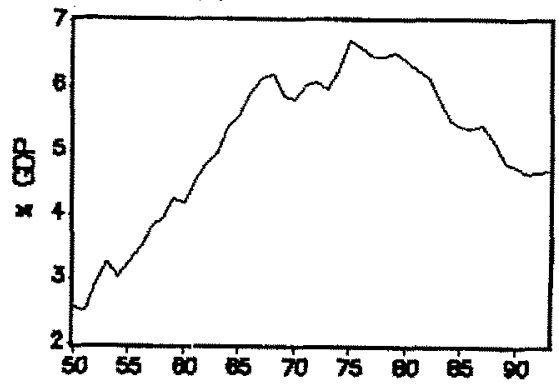

(d) HEALTH CARE

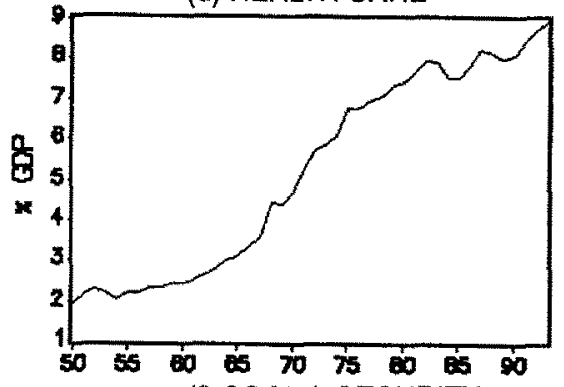

(f) SOCIAL SECURITY

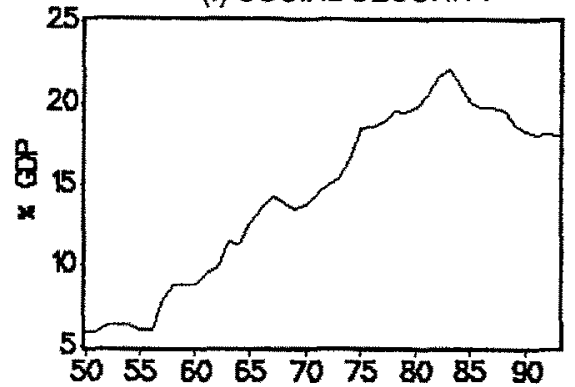

Figure 1.

a clear upward trend throughout the sample period. The empirical results presented in the next section suggest that the ageing of the population may have caused the steady rise in the health care expenditure ratio.

\subsection{Political variables}

To examine whether the various ratios of government expenditures exhibit political cycles we make use of dummy variables and an indicator of the ideology of the government. The dummy variables are meant to capture the idea behind the PBC model that incumbents try to show better economic performance near elections than at other times in order to increase their prospects for reelection. In principle, the incumbent can do so in two ways. 
First, they can try to make voters feel wealthier when casting their ballots by increasing visible government expenditures, such as transfers, just before elections. This is the conventional view on the PBC model (see, e.g., Tufte, 1978). Second, incumbents may signal favourable economic circumstances through proposals for relatively large spending increases in the budget acts at the end of their administrative terms. (cf. Hackl, Schneider, and Withers, 1993). Because there exists a time lag between the approval of the budget act by parliament and the implementation of the policy plans, the plans become only effective after elections are held. Thus this view on the PBC model suggests that government spending may increase after elections rather than before elections. To account for both views on the PBC model in the empirical analysis, we use the following three dummy variables:

$$
\begin{aligned}
& \text { dum }_{b}= 1 \text { in the year before every planned election year and is zero } \\
& \text { otherwise; }
\end{aligned}
$$

As the descriptions of the dummy variables suggest, we only allow for electoral effects around planned election years. In the Netherlands (1952-1994 period), five out of thirteen elections were by-elections which were held because the government resigned before their (four years) terms had been completed.

To test for partisan cycles in the various government expenditure ratios we have constructed an indicator of the ideology of Dutch post-war coalitions. This indicator is defined as follows:

$$
\mathrm{IDEOL}=\frac{\mathrm{M}_{\mathrm{L}}-\mathrm{M}_{\mathrm{R}}}{\mathrm{M}_{\mathrm{L}}+\mathrm{M}_{\mathrm{C}}+\mathrm{M}_{\mathrm{R}}}
$$

where $M_{L}, M_{R}$ and $M_{C}$ denote the number of left-wing, right-wing and ministers of the center in a cabinet, respectively. Ministers who were not a member of a political party are excluded from this variable. Table 1 shows how the number of ministers of left-wing, centre and right-wing parties has varied over time for the period 1946-1994. Ministers of the centre political persuasion (CDA and before 1977: ARP, CHU, KVP) are assumed to have a neutral role in the explanation of government spending cycles. This is not to say that they have no (explanatory) power at all. The ministers of the centre parties dampen the influence of left-wing or right-wing ministers by influencing the numerator of the IDEOL definition.

As discussed above, there is a time-lag between the design of policy and its implementation. For this reason, partisan cycles do not exactly coincide 
Table I. Number and colour of cabinets ministers, the Netherlands 1946-1994

\begin{tabular}{llrrrrr}
\hline Period & Cabinet & \multicolumn{5}{c}{ Number of ministers } \\
\cline { 3 - 7 } & & Left-wing & Centre & Right-wing & $\begin{array}{l}\text { Not a member } \\
\text { of a party }\end{array}$ & Total \\
\hline $1946-48$ & Beel I & 6 & 5 & - & 3 & 14 \\
$1948-51$ & Drees-Van Schaik & 5 & 7 & 1 & 2 & 15 \\
$1951-52$ & Drees I & 5 & 8 & 1 & 1 & 15 \\
$1952-56$ & Drees II & 5 & 10 & - & 1 & 16 \\
$1956-58$ & Drees III & 5 & 9 & - & - & 14 \\
$1958-59$ & Beel II & - & 10 & - & - & 10 \\
$1959-63$ & De Quay & - & 10 & 3 & - & 13 \\
$1063-65$ & Marijnen & - & 10 & 3 & - & 13 \\
$1965-66$ & Cals & 5 & 9 & - & - & 14 \\
$1966-67$ & Zijlstra & - & 13 & - & - & 13 \\
$1967-71$ & De Jong & - & 11 & 3 & - & 14 \\
$1971-72$ & Biesheuvel I & 2 & 11 & 3 & - & 16 \\
$1972-73$ & Biesheuvel II & - & 11 & 3 & - & 14 \\
$1973-77$ & Den Uyl & 10 & 6 & - & - & 16 \\
$1977-81$ & Van Agt I & - & 10 & 6 & - & 16 \\
$1981-82$ & Van Agt II & 9 & 6 & - & - & 15 \\
$1982-82$ & Van Agt III & 5 & 9 & - & - & 14 \\
$1982-86$ & Lubbers I & - & 8 & 6 & - & 14 \\
$1986-89$ & Lubbers II & - & 9 & 5 & - & 14 \\
$1989-94$ & Lubbers III & 7 & 7 & - & - & 14 \\
$1994-$ & Kok & 9 & - & 5 & - & 14 \\
\hline Source: Dag & & & & & 14 \\
1
\end{tabular}

Source: Daalder and Schuyt (1991).

Note. Centre parties are: $\mathrm{CDA}=$ Christian Democrats, $\mathrm{CHU}=$ Christian Historical Union, $\mathrm{ARP}=$ Protestant Party, KVP = the Catholic Party. The parties KVP, ARP, CHU merged in 1977 into the general confessional party Christian Democratic Appeal. Left-wing parties are: D'66 = Democrats '66, DS'70 = Democratic Socialists 1970, PvdA = Labour Party. The right-wing party is VVD = Conservative Party.

with changes in the composition of cabinets. To assess the lags of the effect of IDEOL on government spending, we have included $\mathrm{IDEOL}_{\mathrm{t}}$ in the regressions of the government spending ratios with various lags.

\section{The empirics of government spending}

This section reports some simple regressions of the ratios of the public spending categories (relative to GDP) on the political variables discussed above. As a starting point for the empirical analysis serves equation (1) which, after 
taking logarithms, can be rewritten as;

$$
\begin{aligned}
\mathrm{g}_{\mathrm{i}}+\mathrm{p}_{\mathrm{i}}-\mathrm{y}-\mathrm{p}_{\mathrm{y}}= & \left(\alpha_{1}-1\right)\left(\mathrm{y}-\mathrm{p}_{\mathrm{y}}\right)+\left(\alpha_{2}+1\right)\left(\mathrm{p}_{\mathrm{i}}-\mathrm{p}_{\mathrm{y}}\right) \\
& +\left(\alpha_{3}-\alpha_{1}\right) \mathrm{n}+\Sigma \beta_{\mathrm{i}} \mathrm{z}_{\mathrm{i}}
\end{aligned}
$$

where lowercase letters indicate logarithms of the variables described in equation (1) and $z_{i}$ represents all other variables (business cycle, demographics) including the electoral dummy variables and the indicator of ideology. To test the implications of the Rogoff model and to examine the empirical relevance of the Tabellini-Alesina model we examine government behaviour on a relatively low level of aggregation. The public expenditure categories include expenditures on defense, infrastructure, public administration, health care, education and social security transfers. Other spending categories such as subsidies (to consumers and producers) and foreign government transfers have been excluded from our analysis because these categories are too hybrid to yield meaningful conclusions.

Most of the time series of public spending have autoregressive properties. We have added autoregressive terms to the regressions to correct for them. The number of autoregressive terms are based on the Lagrange Multiplier (LM) test. Although we mark some of these expenditures as public goods, we are well aware that indivisibilities in the use of public services and goods are quite common. Since equation (3) typically pertains to goods and services that are characterized by various degrees of indivisibility and non-excludability, we emphasize the results for spending on public and quasi-public goods. The results for social security transfers should be regarded as illustrative. Probably, a different type of model should be used for this particular category (see, e.g., Kristov, Lindert, and McClelland, 1992).

We have carried out the empirical analysis in two steps. First, we estimated the general form of (3), including the three electoral dummy variables and the lagged indicators of ideology.

Table 2 reports the estimates obtained in step 1.

The first three rows of the second part (below the dotted line) in Table 2 report the estimates of the three electoral dummy variables for the various government spending categories. Overall, the estimation results provide evidence in support of the political business cycle theory. All government spending categories, perhaps with the exception of health care, tend to rise near planned election years. However, Table 2 shows some variation in the timing of the electoral cycles across government spending categories. Only the estimation results for public spending on defense (and perhaps social security transfers) are consistent with the conventional view on the PBC theory that government spending rises just before elections. Our findings for infrastructure and education expenditures seem to be consistent with the alternative view that 
Table 2. Election and partisan cycles in the various government expenditure ratios

\begin{tabular}{|c|c|c|c|c|c|c|}
\hline & \multicolumn{6}{|c|}{ Dependent variable: Government spending (as \% in GDP) in: } \\
\hline & \multicolumn{3}{|c|}{ Public goods } & \multicolumn{2}{|c|}{ Quasi-public goods } & \multirow{2}{*}{$\begin{array}{l}\text { Transfers } \\
\text { Social } \\
\text { security } \\
\text { equation }\end{array}$} \\
\hline & $\begin{array}{l}\text { Defense } \\
\text { equation }\end{array}$ & $\begin{array}{l}\text { Infrastructure } \\
\text { equation }\end{array}$ & $\begin{array}{l}\text { Public } \\
\text { administration } \\
\text { equation }\end{array}$ & $\begin{array}{l}\text { Education } \\
\text { equation }\end{array}$ & $\begin{array}{l}\text { Health care } \\
\text { equation }\end{array}$ & \\
\hline Income elasticity, & -0.098 & 0.679 & $0.841^{* *}$ & $0.625^{* *}$ & $1.476^{* *}$ & $1.627^{* *}$ \\
\hline$\alpha_{1}$ & $(0.301)$ & $(0.488)$ & $(0.132)$ & $(0.123)$ & $(0.207)$ & $(0.255)$ \\
\hline $\begin{array}{l}\text { Price elasticity, } \\
\alpha_{2}\end{array}$ & $\begin{array}{l}-0.374 \\
(0.236)\end{array}$ & $\begin{array}{l}-1.956^{* *} \\
(0.661)\end{array}$ & $\begin{array}{c}0.159 \\
(0.099)\end{array}$ & $\begin{array}{l}-0.318^{* *} \\
(0.138)\end{array}$ & $\begin{array}{l}-0.969^{* *} \\
(0.188)\end{array}$ & - \\
\hline Population size & $\begin{array}{l}0.239^{* *} \\
(0.067)\end{array}$ & $\begin{array}{l}5.820^{* *} \\
(2.103)\end{array}$ & $\begin{array}{l}-3.100^{* *} \\
(0.592)\end{array}$ & - & $\begin{array}{l}12.403^{* *} \\
(2.159)\end{array}$ & $\begin{array}{c}-12.767^{* *} \\
(2.768)\end{array}$ \\
\hline Constant & $\begin{array}{c}4.647 \\
(5.697)\end{array}$ & $\begin{array}{l}-51.437^{* *} \\
(19.018)\end{array}$ & $\begin{array}{l}30.899^{* *} \\
(5.244)\end{array}$ & $\begin{array}{c}-18.241^{* *} \\
(3.292)\end{array}$ & $\begin{array}{l}-44.016^{* *} \\
(12.722)\end{array}$ & $\begin{array}{l}-23.898 \\
(19.400)\end{array}$ \\
\hline Trend & $\begin{array}{c}0.0014^{*} \\
(0.007)\end{array}$ & $\begin{array}{l}-0.058^{* *} \\
(0.013)\end{array}$ & $\begin{array}{l}0.034^{* *} \\
(0.003)\end{array}$ & $\begin{array}{c}0.016^{* *} \\
(0.004)\end{array}$ & $\begin{array}{l}-0.223^{* *} \\
(0.027)\end{array}$ & $\begin{array}{c}0.057 \\
(0.039)\end{array}$ \\
\hline Old population & - & - & - & - & $\begin{array}{c}3.809^{* *} \\
(1.443)\end{array}$ & $\begin{array}{c}3.405^{*} \\
(1.803)\end{array}$ \\
\hline Young population & - & - & - & $\begin{array}{c}1.585^{* *} \\
(0.256)\end{array}$ & $\begin{array}{l}-4.808^{* *} \\
(0.517)\end{array}$ & $\begin{array}{c}4.279^{* *} \\
(0.783)\end{array}$ \\
\hline $\begin{array}{l}\text { Unemployment } \\
\text { rate }\end{array}$ & - & - & - & - & $\begin{array}{l}1.993^{* *} \\
(0.294)\end{array}$ & $\begin{array}{l}3.116^{* *} \\
(0.295)\end{array}$ \\
\hline $\mathrm{ELEC}_{\mathrm{b}}$ & $\begin{array}{c}0.008 \\
(0.017)\end{array}$ & $\begin{array}{c}0.013 \\
(0.033)\end{array}$ & $\begin{array}{c}0.032^{* *} \\
(0.014)\end{array}$ & $\begin{array}{c}0.004 \\
(0.012)\end{array}$ & $\begin{array}{c}0.016 \\
(0.017)\end{array}$ & $\begin{array}{r}0.038^{*} \\
(0.020)\end{array}$ \\
\hline $\mathrm{ELEC}_{\mathrm{c}}$ & $\begin{array}{c}0.070^{* *} \\
(0.023)\end{array}$ & $\begin{array}{c}0.055 \\
(0.035)\end{array}$ & $\begin{array}{c}0.034^{* *} \\
(0.016)\end{array}$ & $\begin{array}{c}0.013 \\
(0.012)\end{array}$ & $\begin{array}{c}0.010 \\
(0.015)\end{array}$ & $\begin{array}{c}0.043^{* *} \\
(0.014)\end{array}$ \\
\hline $\mathrm{ELEC}_{\mathrm{a}}$ & $\begin{array}{c}0.014 \\
(0.014)\end{array}$ & $\begin{array}{r}0.060^{*} \\
(0.031)\end{array}$ & $\begin{array}{c}0.033^{* *} \\
(0.013)\end{array}$ & $\begin{array}{c}0.034^{* *} \\
(0.011)\end{array}$ & $\begin{array}{c}0.015 \\
(0.014)\end{array}$ & $\begin{array}{c}0.042^{* *} \\
(0.018)\end{array}$ \\
\hline IDEOL $_{-1}$ & $\begin{array}{l}-0.033^{* *} \\
(0.016)\end{array}$ & $\begin{array}{l}-0.076 \\
(0.045)\end{array}$ & $\begin{array}{c}0.004 \\
(0.024)\end{array}$ & $\begin{array}{c}0.003 \\
(0.011)\end{array}$ & $\begin{array}{c}0.000 \\
(0.018)\end{array}$ & $\begin{array}{c}0.028 \\
(0.021)\end{array}$ \\
\hline $\mathrm{IDEOL}_{-2}$ & $\begin{array}{l}-0.018 \\
(0.014)\end{array}$ & $\begin{array}{c}0.009 \\
(0.047)\end{array}$ & $\begin{array}{c}0.015 \\
(0.011)\end{array}$ & $\begin{array}{c}0.006 \\
(0.012)\end{array}$ & $\begin{array}{l}0.044^{* *} \\
(0.019)\end{array}$ & $\begin{array}{c}0.043^{* *} \\
(0.020)\end{array}$ \\
\hline AR & 4 & 1 & 1 & 0 & 3 & 3 \\
\hline Sample period & $1957-93$ & $1954-93$ & 1954-93 & $1953-93$ & $1956-93$ & $1957-92$ \\
\hline Adj. $\mathbf{R}^{2}$ & 0.979 & 0.934 & 0.978 & 0.987 & 0.997 & 0.989 \\
\hline
\end{tabular}

Note. Estimated with OLS, standard errors are in parentheses. The symbols ${ }^{* *}$ denote significance at the $5 \%$ level and ${ }^{*}$ significance at the $10 \%$ level. The test-statistics at the bottom of the table denote the following: $A R$ is the number of autoregressive terms, adj. $R^{2}$ is the adjusted correlation coefficient. 
public spending rises after elections are held. Finally, the electoral cycle in expenditure on public administration (and perhaps transfers) is consistent with both versions of the PBC model. The last two rows of Table 2 report the estimation results concerning the partisan effects. The estimates suggest that transfer payments tend to be higher under left-wing cabinets than under right-wing cabinets. In contrast, public spending on defense and infrastructure is relatively low under left-wing cabinets. Furthermore the estimation results indicate that the effect of IDEOL on government spending has a lag of one to two years.

Next we estimate the specific form of equation (3). In those cases where the political effects reported in Table 2 exceed one year, combinations of dummy variables can be used. For example, as to the social security transfers we can replace the three dummy variables with a single dummy variable, being 1 before, after and in the (planned) election years and zero in other years. Table 3 reports the second step of the estimation procedure: the estimation results of the specific form equations where combinations of dummy variables are included in the regressions. All variables whose t-statistics are smaller than 1 in absolute terms are excluded from the regressions. Moreover, combinations of dummy variable are used when the restriction $\operatorname{dum}_{i}=\mathbf{d u m}_{\mathbf{j}}$ $(i, j=b, e, a$ and $i \neq j)$ is not rejected at a five percent significance level.

Let us first consider the estimation results applying to the public goods model. Globally, our results are similar to the findings reported in comparable studies (cf. Borcherding, 1985): the income elasticity, $\alpha_{1}$, lies in the interval $(0,1)$, save health care and social security transfers, and the price elasticity, $\alpha_{2}$, lies in the interval $(-1,0)$. The latter value implies that for the relative growth in government size the price of government goods must have risen relative to private goods. Empirical evidence (see Central Planning Bureau, 1994) suggests that this has been the case for the sample period 1950-1990: the price of government goods was higher than the price of private goods with the exception of period 1981-1987 in which the price of government-provided goods dropped relative to the price of private goods. Table 3 also presents some clear exceptions to the rule: the income elasticity of defense expenditure, the price elasticity of public administration, the price elasticity of defense and the income elasticity of infrastructure are not consistent with the predictions of the public goods model. Explaining these anomalous findings is going to be a speculative affair. The fact that price theoretic principles of the median voter model do not fit the defense expenditure model is perhaps a consequence of the fact that decision making on defense spending is subject to erratic events. The aftermath of the military involvement in the Dutch Indies, the fear for the Cold War and international defense arrangements have played a dominant role in determining the defense budget. For the public administration expenditures 
the reason for a positive (but insignificant) price elasticity can perhaps be traced to the fact that the 'good' public administration is a labour intensive one, hence the price of public administration is dominated by the development of the wages of civil servants. Given the fact that the expenditures on public administration move in tandem with the demand for goods and transfers such as health care, education and social security the sensitivity of the demand for public administration to price movements will not be too strong.

As mentioned earlier, the spending category 'transfers' is quite difficult to capture in standard theory. As one can see the significant and large effect of the old population of 65 years and over and the rate of unemployment go a long way in explaining the growth in transfers, while the large effect of the growth in income can be explained by the initiative to link the social security benefits to wage rate developments in the private sector.

However, the central theme of this paper does not revolve around the traditional model. The central question is: do political motives matter? Below the dotted line in Table 3 we report some results which suggest they do matter. As one can see from the rows that contain electoral dummy variables $\left(E L E C_{i}\right)$, rather strong effects originating from electoral motives show up in the data: the opportunistic variables all have the right sign and are significant at (at least) the five percent level (excluding the category 'health care'). As one would expect the category social security is heavily affected by the pressures brought about by election times. Most of the opportunistic measures aimed at influencing election outcomes are felt only in one case during the election year itself $\left(\mathrm{ELEC}_{\mathrm{e}}\right.$ ), viz. for the defense expenditures (see notes below Table 3). One more noteworthy point that one might overlook is the fact that we have examined planned elections. Contrary to, for example the U.S., Dutch cabinets can be dismissed by parliament and subsequent by-elections are marked as unexpected. Once we estimate the effect of all elections, planned and unplanned, the electoral effect becomes less important.

As one can deduce from Table 3 the development of government spending is also affected by the colour of the cabinet: the ideological variables $\mathrm{IDEOL}_{-t}$ is statistically significant with the exception of expenditure categories education and public administration. The empirical results indicate that left-wing administrations tend to spend more on health care and transfers, while rightwing administrations spend more on infrastructure and defense. These results seem to be consistent with the main idea behind the partisan theory that leftwing parties cater to the desires of low income groups, since expenditures on health care and social security benefits seem effective means to redistribute income from the rich to the poor. The insignificance of ideological motives in educational spending can be explained by multi-faced aspects of educational services: for left-wing ministers they are the means to establish a more equi- 
Table 3. Partisan and election cycles in government spending, the Netherlands

\begin{tabular}{|c|c|c|c|c|c|c|}
\hline & \multicolumn{6}{|c|}{ Dependent variable: Government spending (as \% in GDP) in: } \\
\hline & \multicolumn{3}{|c|}{ Public goods } & \multicolumn{2}{|c|}{ Quasi-public goods } & \multirow{2}{*}{$\begin{array}{l}\text { Transfers } \\
\text { Social } \\
\text { security } \\
\text { equation }\end{array}$} \\
\hline & $\begin{array}{l}\text { Defense } \\
\text { equation }\end{array}$ & $\begin{array}{l}\text { Infrastructure } \\
\text { equation }\end{array}$ & $\begin{array}{l}\text { Public } \\
\text { administration } \\
\text { equation }\end{array}$ & $\begin{array}{l}\text { Education } \\
\text { equation }\end{array}$ & $\begin{array}{l}\text { Health care } \\
\text { equation }\end{array}$ & \\
\hline Income elasticity, & -0.229 & 0.612 & $0.921^{* *}$ & $0.627^{* *}$ & $1.405^{* *}$ & $1.628^{* *}$ \\
\hline$\alpha_{1}$ & $(0.234)$ & $(0.449)$ & $(0.090)$ & $(0.115)$ & $(0.185)$ & $(0.238)$ \\
\hline Price elasticity, & -0.276 & $-1.967^{* *}$ & 0.226 & $-0.285^{* *}$ & $-0.863^{* *}$ & - \\
\hline$\alpha_{2}$ & $(0.189)$ & $(0.544)$ & $(0.776)$ & $(0.125)$ & $(0.156)$ & \\
\hline \multirow[t]{2}{*}{ Population size } & 0.201 & $6.110^{* *}$ & $-3.708^{* *}$ & - & $12.999^{* *}$ & $-12.787^{* *}$ \\
\hline & $(0.588)$ & $(1.971)$ & $(0.375)$ & & $(1.469)$ & $(2.577)$ \\
\hline \multirow[t]{2}{*}{ Constant } & 3.399 & $-53.886^{* *}$ & $36.283^{* *}$ & $-17.440^{* *}$ & $-44.638^{* *}$ & -23.246 \\
\hline & $(5.122)$ & $(17.128)$ & (3.341) & $(2.937)$ & $(10.852)$ & $(17.389)$ \\
\hline \multirow[t]{2}{*}{ Trend } & $0.015^{*}$ & $-0.058^{* *}$ & $0.036^{* *}$ & 0.016 & $-0.221^{* *}$ & 0.054 \\
\hline & $(0.007)$ & $(0.012)$ & $(0.002)$ & $(0.009)$ & $(0.020)$ & $(0.035)$ \\
\hline \multirow[t]{2}{*}{ Old population } & - & - & -- & - & $3.461^{* *}$ & $3.521^{*}$ \\
\hline & & & & & $(1.049)$ & $(1.607)$ \\
\hline \multirow[t]{2}{*}{ Young population } & - & - & -- & $1.495^{* *}$ & $-4.863^{* *}$ & $4.245^{* *}$ \\
\hline & & & & $(0.227)$ & $(0.458)$ & $(0.714)$ \\
\hline \multirow{2}{*}{$\begin{array}{l}\text { Unemployment } \\
\text { rate }\end{array}$} & 0.728 & - & - & - & $1.926^{* *}$ & $3.143^{* *}$ \\
\hline & $(0.555)$ & & & & $(0.257)$ & $(0.273)$ \\
\hline $\mathrm{ELEC}_{\mathrm{e}}$ & $\begin{array}{c}0.065^{* *} \\
(0.019)\end{array}$ & - & - & - & - & - \\
\hline $\mathrm{ELEC}_{\mathrm{a}}$ & $\begin{array}{c}0.010 \\
(0.010)\end{array}$ & - & - & - & - & - \\
\hline $\mathrm{ELEC}_{\mathrm{ca}}$ & - & $\begin{array}{c}0.102^{* *} \\
(0.047)\end{array}$ & -- & $\begin{array}{c}0.045^{* *} \\
(0.010)\end{array}$ & - & - \\
\hline ELEC $_{\text {bea }}$ & - & - & $\begin{array}{c}0.091^{* *} \\
(0.029)\end{array}$ & - & - & $\begin{array}{c}0.122^{* *} \\
(0.042)\end{array}$ \\
\hline IDEOL $_{-1}$ & - & $\begin{array}{l}-0.073^{*} \\
(0.039)\end{array}$ & - & - & - & - \\
\hline IDEOL_-2 & - & - & - & - & $\begin{array}{l}0.036^{* *} \\
(0.011)\end{array}$ & - \\
\hline IDEOL $_{-12}$ & $\begin{array}{l}-0.055^{*} \\
(0.026)\end{array}$ & - & - & - & - & $\begin{array}{c}0.072^{* *} \\
(0.019)\end{array}$ \\
\hline AR & 4 & 1 & 1 & 0 & 3 & 3 \\
\hline Sample period & $1957-93$ & 1954-93 & $1954-93$ & $1953-93$ & $1956-93$ & $1957-92$ \\
\hline Adj. $\mathrm{R}^{2}$ & 0.985 & 0.951 & 0.982 & 0.989 & 0.998 & 0.994 \\
\hline
\end{tabular}

Note. Estimated with OLS, standard errors are in parentheses. The symbols ${ }^{* *}$ denote significance at the 5\% level and ${ }^{*}$ significance at the $10 \%$ level. The test-statistics at the bottom of the table denote the following: $A R$ is the number of autoregressive terms, adj. $R^{2}$ is the adjusted correlation coefficient. The following political variables are used in the analysis: the eleciton dummy $\mathrm{ELEC}_{\varepsilon}$;

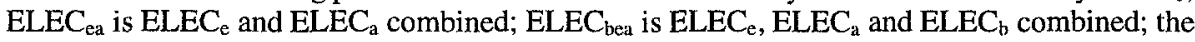
Ideological variables IDEOL $_{-1}$; IDEOL -2 ; and IDEOL -12 denotes the unweighted average of IDEOL $_{-1}$ and IDEOL $_{-2}$. 
table primary income distribution and for right-wing ministers education is an investment good that might stimulate economic growth.

How are the empirical results related to the predictions of the recent political economic models? Clearly, our results are in line with the main assumption underlying the Tabellini and Alesina (1990) model that political parties disagree about the composition of public spending. This might make the Netherlands an interesting case to examine the main hypothesis of their model, viz. that the party in office runs budget deficits to constrain its successor. Though we have detected clear political business cycles in government spending data, our results are not fully consistent with the Rogoff (1990) model. In the Rogoff model, policy makers are predicted to increase public expenditure on highly visible goods, perhaps at the expense of expenditures on less visible good (see for an interesting counterargument on the visibility of public goods a contribution by Downs, 1962). Our results indicate that policy makers tend to increase expenditures on all goods, whether they are visible or 'invisible'. One interpretation of our results is that around election time policy makers are inclined to give in to the pressures of interest groups to avoid conflicts.

\section{Conclusions}

Is fiscal policy used to fool the public in electoral competition or is it used to realize the ideological goals of the policy makers in office? At different points in time authors have stressed either the 'opportunistic' policy maker as the dominant figure behind the design of economic policy or the 'partisan' policy maker. Our empirical results suggest that economic policy is induced by a mixture of motives and our empirical analysis for the post-war Dutch economy supports this view. Both models of the policy maker appear to be applicable to the Dutch case. To start with the opportunistic model of policy making: government spending for every type of public good or service is always increased during elections. This finding diverges from the Rogoff (1990) assertion that politicians use government spending on highly visible goods to show off their competence, and as he points out the electoral budget cycle "may be a socially efficient mechanism for diffusing up-to-date information about the incumbent's administrative competence" (p.22). We show, however, that Dutch politicians increase spending on visible goods as well as goods with a low media profile.

Besides peddling for votes during the elections the Dutch policy maker is found to satisfy the ideological goals he was elected for. The ideological motives appear to be significant in explaining government spending: spending is increased by left-wing cabinets on quasi-public goods (health care) and social security transfers that favour their traditional low-income constituency. 
Right-wing cabinets are traditionally more concerned with economic growth, national defense and private responsibility in questions of social security and health insurance. The increase in spending on categories such as infrastructure and defense and the decrease in health care spending and social security transfers are merely the consequence of this policy stance.

\section{References}

Alesina, A. (1987). Macroeconomic policy in a two-party system as a repeated game. Quarterly Journal of Economics 102: 651-678.

Alesina, A. (1988). Macroeconomics and politics. In S. Fischer (Ed.), NBER macroeconomics annual 1988. Cambridge MA: MIT Press.

Alesina, A. (1990). Evaluating rational partisan business cycle theory: A response. Economics and Politics 5: 1-30.

Alesina, A., Cohen, G.D., and Roubini, N. (1992). Macroeconomic policy and elections in OECD democracies. In A. Cukierman, Z. Hercowitz, and L. Leiderman (Eds.), Political economy, growth, and business cycles. Cambridge, MA: MIT Press.

Alesina, A. and Rosenthal, H. (1995). Partisan politics, divided government and the economy. Cambridge: Cambridge University Press.

Alesina, A. and Roubini, N. (1992). Political cycles in OECD economies. Review of Economic Studies 59: 663-688.

Bergstrom, T.C. and Goodman, R.P. (1973). Private demands for public goods. American Economic Review 63: 280-296.

Borcherding, T.E. (1985). The causes of government expenditure growth: A survey of the U.S. evidence. Journal of Public Economics 28: 359-382.

Borcherding, T.E. and Deacon, R.T. (1972). The demand for the services of non-federal governments. American Economic Review 62: 891-901.

Central Planning Bureau (1994). De collectieve uitgaven in de periode 1950-1990: Een onderzoek naar de componenten van de quotestijging. Werkdocument no. 67, The Hague.

Daalder, H. and Schuyt, C.J.M. (1991). Compendium voor politiek en samenleving in Nederland. Houten: Bohn Stafleu/Van Loghum.

Downs, A. (1962). Why the government budget is too small in a democracy. In E.S. Phelps (Ed.), Private wants and public needs: Issues surrounding the size and scope of government expenditure. New York: Norton.

Frey, B.S. and Schneider, F. (1978a). An empirical study of politico-economic interaction in the United States. Review of Economics and Statistics 60: 174-183.

Frey, B.S. and Schneider, F. (1978b). A politico-economic model of the United Kingdom. Economic Journal 88: 243-253.

Hackl, F., Schneider, F., and Withers, G. (1993). The public sector in Australia: A quantitative analysis. In N. Gemmel (Ed.), The growth of the public sector. Aldershot: Edward Elgar, Gower House.

Haynes, S.E. and Stone, J.A. (1989). An integrated test for electoral cycles in the U.S. economy. Review of Economics and Statistics 426-434.

Hibbs, D. (1977). Political parties and macroeconomic policy. American Political Science Review 71: 1467-1487.

Kalecki, M. (1943). Political aspects of full employment. Political Quarterly 14: 322-331, reprinted in: M. Kalecki, 1971, Selected Essays on the Dynamics of the Capitalist Economy, 1933-1970, Cambridge: Cambridge University Press.

Kristov, L., Lindert, P., and McClelland, R. (1992). Pressure groups and redistribution. Journal of Public Economics 48: 135-163. 
Lucas, R.E. Jr. (1976). Econometric policy evaluation: A critique. Carnegie Rochester Conference Series on Public Policy 1: 19-46.

McCallum, B.T. (1978). The political business cycle: An empirical test. Southern Economic Journal 44: 505-515.

Mueller, D.C. (1989). Public Choice II. Cambridge: Cambridge University Press.

Nordhaus, W.D. (1975). The political business cycle. Review of Economic Studies 42: 169-190.

Persson, T. and Tabellini, G. (1990). Macroeconomic policy, credibility and politics. London: Harwood Academic Press.

Renaud, P.S.A. and Van Winden, F.A.A.M. (1987). On the importance of elections and ideology for government policy in a multi-party system. In M.J. Holler (Ed.), The logic of multi-party systems. Dordrecht: Martinus Nijhoff.

Rogoff, K. (1990). Equilibrium political budget cycles. American Economic Review 80: 21-36.

Rogoff, K. and Sibert, A. (1988). Equilibrium political business cycles. Review of Economic Studies 55: 1-16.

Tabellini, G. and Alesina, A. (1990). Voting on the budget deficit. American Economic Review 80: $37-52$.

Tufte, E.R. (1978). Political control of the economy. Princeton NJ: Princeton University Press. 


\section{Appendix: Definitions government expenditure}

The data on government expenditures are based on those presented by the Central Planning Bureau (CPB, 1994). The definitions that are used by the CPB are also used in this paper. ${ }^{1}$ The following elements of government spending across departments and social insurance services are accounted for in the construction of the aggregate expenditure categories.

1. Defense:

2. Infrastructure:

3. Public administration: wages, net consumption, investment (by federal government, other public institutions and social insurance);

4. Education:

5. Health care:

6. Social security:

wages, net consumption;

investments in land, roads and water constructions (federal government and other public institutions), capital transfers to firms for land, roads and water works (National Railway);

wages, net consumption and investment; national health fund, AWBZ, homes for the oldaged contributions to non-profit health institutions, wealth transfers to households;

Disability insurance: WAO/AWW, ZW, IW, WSW

Demographically related/old-aged: NWOD, AOW, AWW, VUT (early retirement benefits government employees)

Demographically related/young: AKW/grants

Unemployment: WW, RWW, WWV, IOAW, IOAZ, TW

Welfare: ABW (excl. RWW), benefits persecution victims, extraordinary pensions, income and wealth transfers to pension funds, wealth transfers to households.

The price figures for defense, public administration, health care and education expenditure are the weighted average of wage costs, net government consumption and capital consumption. The development of the price of infrastructure has been fixed at the price of gross government investment. In constructing

\footnotetext{
${ }^{1}$ We gratefully acknowledge the help of Harry ter Rele (CPB) in providing us with Dutch government expenditure data.
} 
these government 'production' figures it is assumed that there is no growth in labour productivity.

List of abbreviations

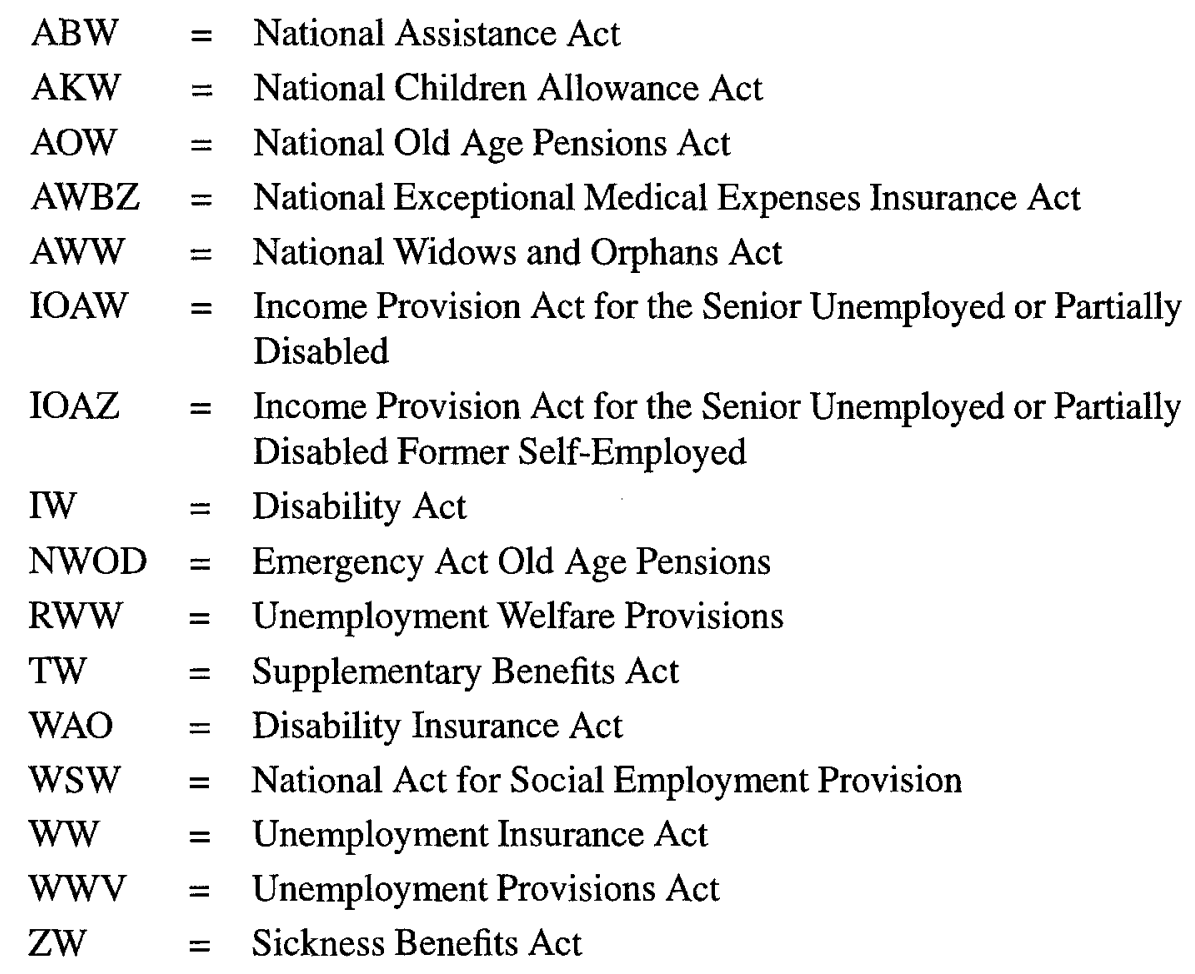

